日耳鼻 105:29-32, 2002

中野 友明

愛場 庸雅

杉田 雅彦

塩谷 隼人

山田 浩二

鶇山 太-

大阪市立総合医療センター 小児耳鼻咽喉科

\section{$9 \mathrm{p}$-症候群に伴った先天性正中鼻瘦孔の 1 例}

先天性正中鼻瘦孔㥛めてま机な奇形疾患の一つとされている。また $9 \mathrm{p}$-症候 群は 9 番染色体短腕の部分欠損を示寸染色体異常症であり，1973年にAlfiに よって初めて報告された疾患概念である。

鼻柱基部に瘦孔を有し, 前頭蓋底に達する先天性正中鼻痽孔を伴った $9 \mathrm{p}$-症候 群の 1 例を経験したので報告した。患者は 1 歳の男児である。在胎39週，正常分

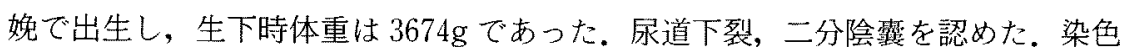
体検査にて第 9 染色体短腕 (p) p 23を切断点と方る欠失を認めた。

CT ならびにMRIにて鼻尖部に腫瘤を認め, 連続して鼻中隔内にも腫瘤を認め

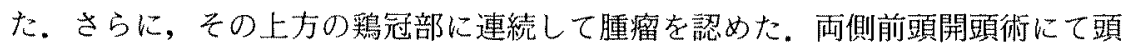
蓋内腫瘤を摘出後, transcolumellar skin incisionにて鼻部腫瘤を摘出した。術 後は感染の併発もなく，経過は良好である。

キーワード：正中畀瘦孔，9p-症候群，染色体異常
はじめに

先天性正中鼾瘦孔は極めてまれな奇形の一つとされ， 本邦において若干例の報告12)があるにすぎない。しか し，この㾇孔の感染を単なる感染性粉瘤と診断し，本症 と気付かずに経過している症例もあると思われ，実際は もっと多いのではないかと考える.さらに診断が確定し ないまま不完全な摘出術が行われ，再発を繰り返してい る症例もあり，本症の䛦断・治療には一層の注意が必要 である.また, $9 \mathrm{p}$-症候群は 9 番染色体短腕の部分欠損を 示す染色体異常症であり，1973年 Alfí) らによって初め て報告された疾患概念である。これも本邦において若干 例の報告"゙があるだけである。

われわれは鼻柱基部に瘦孔を有し，前頭蓋底に達する 先天性正中鼻瘦孔を伴った $9 \mathrm{p}$-症候群の1例を経験した ので，若干の文献的考察を加え報告する。

\section{症例}

患者: 1 歳, 男

\section{主訴：鼻尖部腫脹}

家族歴：父親29歳，母親28歳で患児は第 2 子として出 生した。両親の染色体に異常は認めなかった。

既往歴: 在胎 39 週, 正常分娩で出生し, 生下時体重は

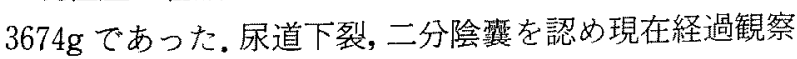

中である、また左先天性耳瘦孔をも認めた。染色体検査 にて第 9 染色体短腕 (p) p23 を切断点とする欠失を認め た.

現病歷：生下時より鼻柱基部に瘦孔があり，鼻尖部の 発赤・腫脹を認めるようになったため他院を受診し, 当 科を紹介され平成11年10月受診した（図 1 ).

CT：鼻尖部より鼻中隔内を走行し頭蓋底に達する翟 胞状腫瘤を認めた（図 2 ）。

MRI：鼻尖部に腫瘤を認め, 連続して舅中隔内にも腫 瘤を認めた。さらにその上方の鶏冠部に連続して腫溜を 認めた.いずれの腫溜も T1にて low intensity, T2にて high intensity を示し辺縁平滑な腫瘤である（図 3 ).

経過：平成12年 4 月に手術を予定していたが, 鼻尖部 腫瘤の発赤, 排膿を認めたため延期となった。平成12年 5 月に小児脳外科とともに手術を施行した. 両側前頭開 頭術にて頭蓋内腫瘤を摘出後, transcolumellar skin incisionにて鼻部腫瘤を摘出した。鼻背皮形と癒着して いる部分があったため，一部皮膚を含めて摘出した (図 4). 術後は感染の併発もなく, 経過は良好である (図 5 ).

病理組織学的所見：皮膚の嵌入に上る瘦孔が見られ，壁 には付属腺が見られ，内容は角質と少数の毛髰からなっ ている(図4)。 


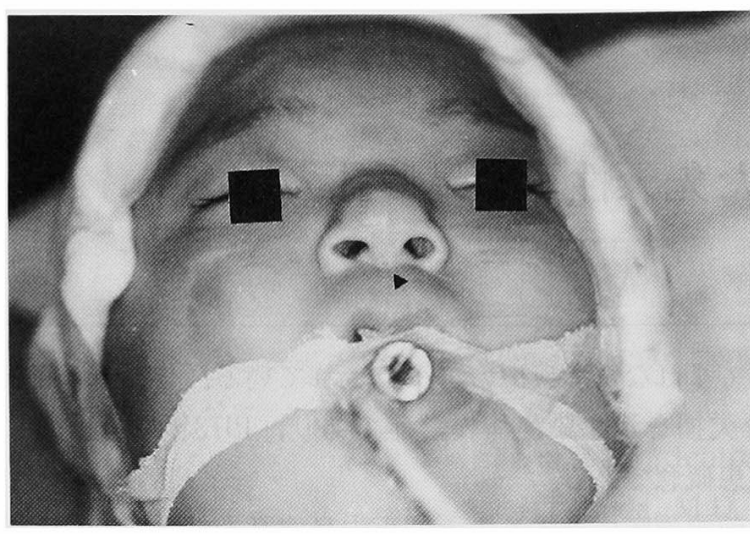

図 1 鼻柱基部に瘻孔を認める.

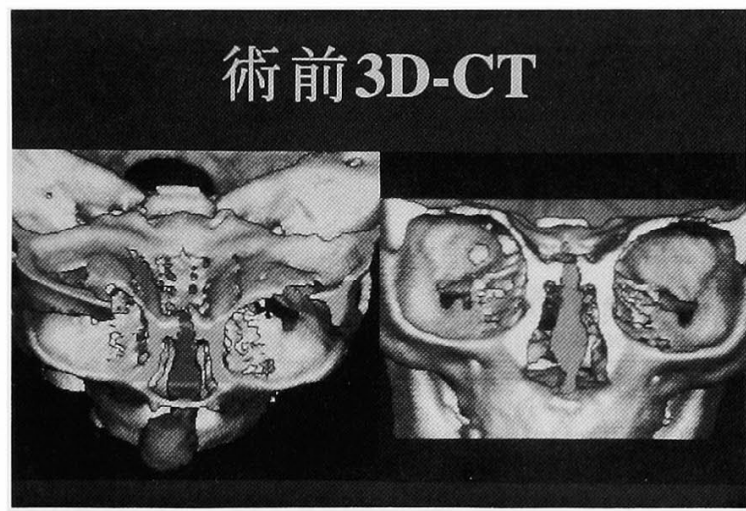

図 2 CT 所見 ; 頭蓋底の骨欠損を認める.

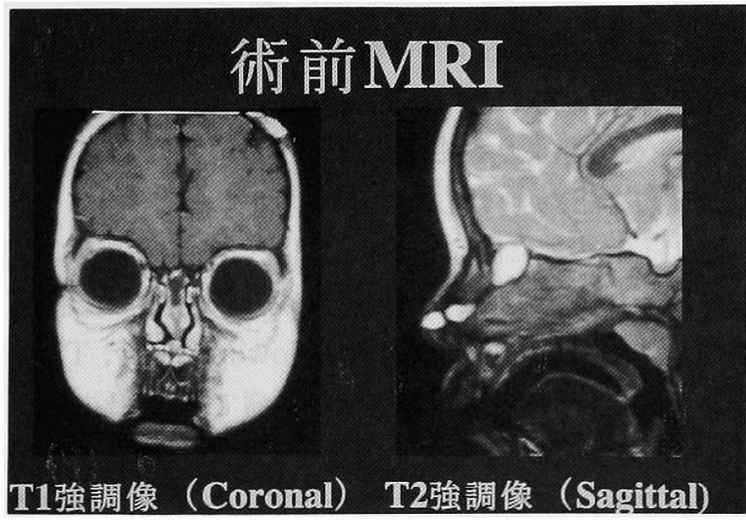

図 3 MRI 所見; 鼻尖部から鼻中隔内に, さらにそ の上方の鶏冠部に連続して腫瘤を認める.

\section{考 察}

正中鼻㾇孔には, 先天性のものと，感染や外傷に続発 するものとがあり，本邦における先天性正中鼻癭孔の報 告は比較的まれである. 白壁ら ${ }^{11}$ は本邦における先天性 正中鼻㾞孔の報告は24例で, 世界では78例の報告があっ たに過ぎないと報告している。

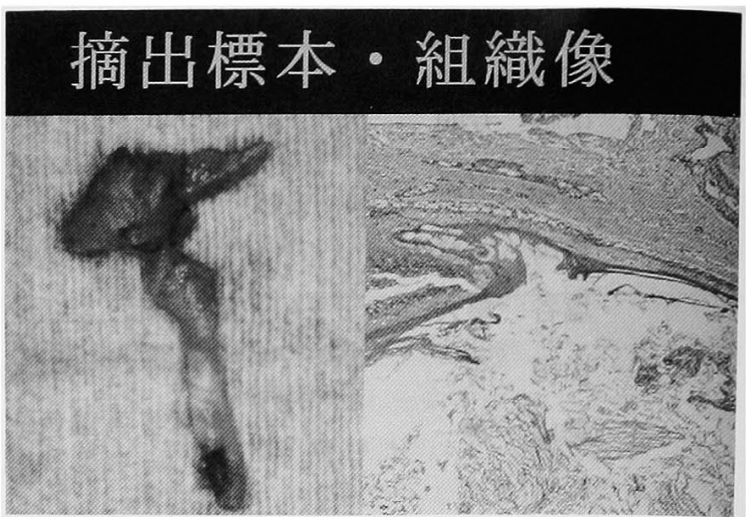

図 4 摘出標本および組織学的所見

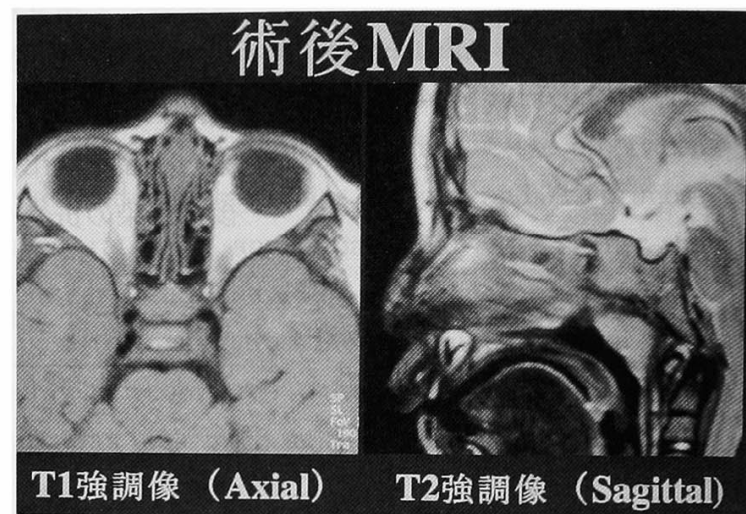

図 5 術後 MRI 所見

成因については星野 ようないくつかの発生機序が想定されている.

1）㾞管が鼻背より鼻骨後面をまわって盲孔の方向へ のびる症例：胎生期に prenasal space に盲孔部より伸 びた脳硬膜が皮膚に接しているが，これが成長に伴って 十分退縮せず皮膚成分が取り残されて瘦管や囊胞が形成 される。

2）㾞管が鼻骨の前面を通つて鼻骨前頭縫合に向かう 症例：胎生期には前頭骨と鼻骨の間に骨がなく, fonticulus frontalisで境されており皮膚と脳硬膜が接 しており同様に皮膚上皮の取り込みが起こり瘦管が形成 される。

3）瘦管が鼻部より蝶形骨洞方向に向かう症例 : 胎生 期初期に前神経孔が閉鎖する際にその部位が蝶形骨洞に 近いため上皮成分が残り瘦管が形成される.

4）瘻管が鼻橋より前鼻棘に伸びる症例：胎生期の顔 面形成の際，突起間の癒合や閉鎖時に上皮が取り込まれ て形成される。

本症の場合，1）の発生機序に相当すると思われる。 診断は鼻正中部の発赤, 腫脹を繰り返すという病歴や 
鼻正中部に瘦孔を認める局所所見より容易である。しか し，本症例のように頭蓋内進展を認める例が William

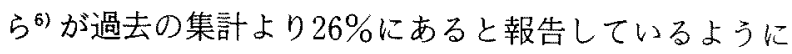
CT, ならびに MRIにて頭蓋内進展の検索は必要と思わ れる. 鑑別診断として粉瘤, 血管腫, 脂肪腫, 神経膠腫, 脳瘤などがある。

治療は手術療法以外にはなく，姑息的な切開や不完全 な手術は再発を起こすため瘦管, 露胞の完全摘出を目指 さなければならない。また完全摘出を行っても数度の再 発をきたした難治性症例の報告もあり ${ }^{21}$, 微細な手術手 技を要する.Jamesら は手術用顕微鏡, 耳用手術器具の 有用性を強調しているが, 本症例の手術でも耳手術用の 器具が大変役に立った。

9p-症候群は 9 番染色体短腕の部分欠損を示す染色体 異常症であり，1973年Alfi ら゙によって初めて報告され た疾患概念である。宮脇ら ${ }^{4)}$ は 9p-症候群の発生頻度は いまだ不明で，国内外合わせて88例の報告がありこの内 訳は男が31例，女が57例であると報告している。

本症候群は, 中程度の精神運動発達遅滞, 三角頭蓋, 眼裂斜上，内眼角贅皮，弓状の眉，扁平な鼻根，前向き な鼻孔をもつ小さな鼻, 長い人中, 耳介低位, 小さな口, 高口蓋または口蓋裂などの特徽的顔貌を示す．そして短 頸, 乳頭離開, 外陰部小奇形などが認められると報告さ れている ${ }^{8}$. 本症例では中程度の精神運動発達遅滞, 三角 頭茲, 内眼角賴皮, 扁平な鼻根, 短頸, 外陰部小奇形な どが諗められた。

最近, この染色体 9 番短腕遠位部部分欠損の発現は後 天性にも認められ，ある種の悪性腫湟細胞に認められて いることから, 染色体 9 番短腕遠位部には悪性腫演との 関連遺伝子が含まれていることが示唆されている。先天 性染色体異常と悪性腫痬との関連性については，ダウン 症候群で白血病の発生率が高いことがすでに報告されて いるが, Nowak ${ }^{91}$ は 9 p-症候群の 9 番染色体短腕遠位部 部分欠損と悪性腫瘍との関連性を指摘している.今後な んらかの悪性腫瘍を発症する可能性もあり, 慎重に経過 観察する予定である。

\section{ま と め}

頭蓋底に進展し脳硬膜に接した先天性鼻正中瘦孔を 伴った 9p-症候群の1例を経験したので若干の文献的考 察を加えて報告した。

\section{参考文献}

1）白壁理志, 田嶋定夫, 上田晃一, 大場創介：正中罩瘦孔 の1例. 形成外科 40(2): 195-198，1997.

2）前 興治, 大森喜太郎, 大森清一：外鼻皮様雅腫の治娩 例. 形成外科 XVII：256-261, 1974.

3) Alfi O, Donnell GN, Crandall BF, Derencsenyi A, Menon R: Deletion of the short arm of chromosome \# $9\left(46,9 \mathrm{p}^{-}\right)$: A new deletion syndrome. Ann Genet 16: 17-22, 1973.

4）宮脇剛司, 新橋 武, 呪島忠雄, 井田博幸: 9p-症候群 の1例. 日形会誌 $16: 398-404,1996$.

5）星野和久: 正中鼻㿉孔と皮胞. JOHNS 7：751-768, 1991.

6) William DC, Byron JB, Charles MS : Nasal dermoid with intracranial involvement. Otolaryngol Head Neck Surg 93: 102-104, 1985.

7) James HK, Marshal S, Bradley H : Surgical update on nasal dermoids. Arch Otolaryngol 108: 239-242, 1982.

8) Huret JL, Leonard C, Forester B, Rethore MO, Lejeune $J$ : Eleven new cases of del $(9 p)$ and features from 90 cases. J Med Genet 25 : 741-749, 1988.

9) Nowak MJ : Deletion 9p syndrome and malignancy: Acquired vs constitutional aberrations? Am J Med Genet $44: 244,1992$.

稿を終えるにあたり大阪市立総合医療センター小児脳神経 外科坂本博昭先生, 北野昌平先生, 森川俊枝先生に樑く感謝い たします。

な㧍本論文の要旨は第275回日本耳鼻咽喉科学会大阪地方 連合会においてロ演した。

(2001年 5 月16日受稿 2001 年 9 月 6 日受理)

別刷請求先 $\overline{\mathbf{T}} 534-0021$ 大阪市都島区都島本通 2-13-22 大阪市立総合医療センター小児耳鼻科 中野友明 
A Case of 9p-deletion Syndrome with Congenital Median Nasal Fistula

Tomoaki Nakano, M.D., Tunemasa Aiba, M.D., Masahiko Sugita, M.D.

Hayato Shiotani, M.D., Kouji Yamada, M.D. and Taichi Uyama, M.D.

Department of Pediatric Oto-Rhino-Laryngology, Osaka City General Hospital, Osaka

We report a case of $9 \mathrm{p}$-syndrome with congenital median nasal fistula in a boy born to a 28-year-old mother as the second child by normal delivery. The fistula opened at the base of the bridge of the nose and ran between the nasal septum cartilage to the anterior cranial fossa. A frontal craniotomy and transcolumellar skin incision were conducted to extirpate the fistula. In the 10 months since, no fistula has recurred.

Keywords : congenital median nasal fistula, 9p-syndrome, transcolumellar skin incision

J Otolaryngol Jpn 105: 29-32, 2002 